\title{
Endometrial spiral artery Doppler parameters in unexplained infertility patients: is endometrial perfusion an important factor in the etiopathogenesis?

\author{
Açıklanamayan infertilite olgularında endometrial spiral arter Doppler \\ parametreleri: endometrial perfüzyon etyopatogenezde önemli bir faktör mü?
}

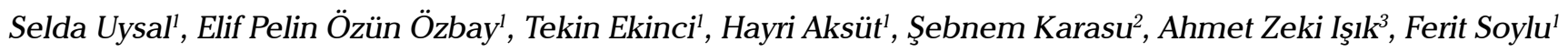 \\ 'Department of Gynecology and Obstetrics, Atatürk Research and Training Hospital, Izmir, Turkey \\ ${ }^{2}$ Department of Radiology, Atatürk Research and Training Hospital, Izmir, Turkey \\ ${ }^{3}$ IRENBE IVF Center, Izmir, Turkey
}

\section{Abstract}

Objective: Uterine perfusion, particularly the endometrial blood flow, may have an important role in endometrial receptivity. In order to assess the contribution of sub endometrial blood flow in the etiopathogenesis of unexplained infertility mid luteal- peri-implantation period spiral artery transvaginal color Doppler parameters were measured and compared with fertile controls.

Material and Methods: Forty-two consecutive patients admitted to Izmir Katip Celebi University Ataturk Training and Research Hospital, Department of Obstetric and Gynecology with the diagnosis of unexplained infertility after standard diagnostic work up constituted the study group and they were compared with a fertile control group admitted to hospital with non specific gynecological complaints or for check-up in the same period. Mid luteal transvaginal color Doppler ultrasonography was applied to each patient by the same radiologist who was blind to the diagnosis of the particular patient and, RI (resistance index) and PI (pulsatility index) values were calculated.

Results: There were no significant differences between the two groups, in respect to age, body mass index, basal hormonal and mid luteal progesterone levels $(p>0.05)$. For the fertile control group, mid luteal-peri-implantation phase endometrial spiral artery mean RI values were calculated as $0.48 \pm 0.08 \mathrm{SD}$ and mean PI values as $0.65 \pm 0.18$ $\mathrm{SD}$. For the study group, mean RI values were calculated as $0.54 \pm 0.07$ $\mathrm{SD}, \mathrm{PI}$ values were calculated as $0.80 \pm 0.16 \mathrm{SD}$. The differences for RI $(\mathrm{p}=0.009)$ and PI $(\mathrm{p}=0.004)$ were statistically significant.

Conclusion: According to Doppler parameters, unexplained infertility patients have high impedance blood flow in spiral arteries which means that peri-implantation blood flow in these patient is lower than fertile controls. These findings suggest that endometrial perfusion may have an important contribution to etiopathogenesis of unexplained infertility. (J Turkish-German Gynecol Assoc 2012; 13: 169-71)

Key words: Unexplained infertility, endometrial blood flow, endometrial receptivity, transvaginal ultrasonograhy, colored Doppler

Received: 13 June, 2012

Accepted: 21 July, 2012

\section{Özet}

Amaç: Endometrial kan akımının, endometrial implantasyonda önemli rol oynadığı düşünülmektedir. Biz çalışmamızda subendometrial kan akımının açıklanamayan infertilitedeki önemini belirleyebilmek için mid-luteal- periimplantasyon dönemindeki kan akımını TVUSG doppler ile ölçerek fertil kontrol grubu ile karşılaştırdik.

Gereç ve Yöntemler: Çalışmamıza İzmir Katip Çelebi Üniversitesi Atatürk Eğitim ve Araştırma Hastanesi, Kadın Hastalıkları ve Doğum Kliniği'ne infertilite nedeni ile başvurmuş ve yapılan tetkikler sonucunda açıklanamayan infertilite olarak tanı almış 42 hasta ile fertilite dışındaki jinekolojik şikayetler ile başvurmuş fertil hastaların midluteal dönemindeki endometrial kan akımı değerlendirildi. Ölçümler; rezistans indeksi ve pulsatilite indeksi, hastaların hangi gruba ait olduğunu bilmeyen tek radyolog tarafından yapıldı.

Bulgular: Yaş, boy, kilo oranı, bazal hormonal durum ve mid-luteal progesteron düzeyleri açısından iki grup arasında fark yoktu ( $p>0.05)$ Fertil kontrol grubunun mid-luteal-peri-implantasyon fazındaki spiral arter ortalama RI değeri $0.48 \pm 0.08 \mathrm{SS}$, PI değeri ise $0.65 \pm 0.18 \mathrm{SD}$ olarak ölçüldü. Çalışma grubu için ise RI değeri $0.54 \pm 0.07 \mathrm{SS}$, PI değeri $0.80 \pm 0.16$ SS olarak ölçüldü. Ölçümler istatistiksel olarak değerlendirildiğinde anlamlı olarak bulundu (RI p:0.009, PI p:0.004).

Sonuç: Doppler parametrelerinin değerlendirilmesi ile, açıklanamayan infertilite grubundaki hastaların, endometrial spiral arter dirençleri kontrol grubundan daha yüksek olarak bulundu. Sonuç olarak açılanamayan infertilite grubundaki hastalarda, periimplantasyon dönemindeki subendometrial kanlanma kontrol grubuna göre daha az olarak ölçülmüştür ve bu sonucun infertilite etyopatogenezinde önemli rol oynadığı düşünülmüştür.

(J Turkish-German Gynecol Assoc 2012; 13: 169-71)

Anahtar kelimeler: Açılanamayan infertilite, endometrial kan akımı, endometrial implantayon, transvajinal ultrasonografi, renkli Doppler

Geliş Tarihi: 13 Haziran $2012 \quad$ Kabul Tarihi: 21 Temmuz 2012 


\section{Introduction}

Unexplained infertility is one of the most common diagnoses in a fertility clinic with the prevalence of $15-30 \%(1,2)$. In fertile women uterine spiral artery perfusion has been found to improve during the luteal phase, which coincides with the implantation window (3). Endometrial receptivity is regulated by many factors including uterine perfusion $(4,5)$. Several studies have shown that uterine receptivity is decreased when the uterine artery impedance has been increased during the mid luteal phase $(2,6)$. Abnormal uterine perfusion may be a contributing factor to etiopathology of infertility especially in couples with unexplained infertility.

Transvaginal Doppler pulsed ultrasound is an important tool for examining the female reproductive system and is a noninvasive method to assess the uterine perfusion $(7,8)$. The aim of this study is to evaluate the mid-luteal phase endometrial spiral artery blood flow in unexplained infertility patients and compare those parameters with fertile controls in order to reveal the possible role of the uterine perfusion in the infertility etiopathogenesis.

\section{Material and Methods}

The study group is composed of consequent 42 unexplained infertility patients admitted to Izmir Katip Celebi University Ataturk Training and Research Hospital, Department at Obstetric and Gynaecology between August 2010 and August 2011. Values of the study groups were compared with 20 volunteers admitted during the same time frame mostly for Pap smear controls. Patients in the control group had normal physical and pelvic examinations with normal menstrual cycles and had given a live birth during the year before the admission and did not have intrauterine device or use oral contraceptives. They were below 40 years of age, did not smoke and did not have any systematic or clinical disease. In the study group, infertility was defined as unexplained if a comprehensive infertility evaluation including transvaginal ultrasonography, mid-luteal progesterone value, histerosalpinghography, detailed semen analysis, failed to reveal any apparent cause.

In this study we measured mid-luteal phase spiral artery parameters by using transvaginal color Doppler ultrasonography (TVCDUSG) in 42 unexplained infertile and 20 fertile patients. TVCDUSG has been performed by the same radiologist, who was blinded to the groups.

Table 1. The mean values of age, BMI, progesterone, FSH and endometrial artery impedance in unexplained infertility group and fertile control group

\begin{tabular}{|l|c|c|c|}
\hline & $\begin{array}{c}\text { Unexplained (n=42) } \\
\text { Mean } \pm \text { SD }\end{array}$ & $\begin{array}{c}\text { Control (n=20) } \\
\text { Mean } \pm \text { SD }\end{array}$ & P \\
\hline Age & $26.69 \pm 4.4$ & $28.25 \pm 3.71$ & 0.176 \\
\hline BMI $\left(\mathrm{kg} / \mathrm{m}^{2}\right)$ & $25.41 \pm 3.31$ & $25.55 \pm 2.61$ & 0.874 \\
\hline Resistance index & $0.54 \pm 0.07$ & $0.48 \pm 0.08$ & 0.009 \\
\hline Pulsatility index & $0.80 \pm 0.16$ & $0.65 \pm 0.18$ & 0.004 \\
\hline Progesteron ng/mL & $10.86 \pm 6.56$ & $10.84 \pm 5.12$ & 0.992 \\
\hline FSH (basal) mIU/mL & $7.6 \pm 1.41$ & $7.58 \pm 1.2$ & 0.941 \\
\hline BMI: Body Mass Index, FSH: Follicule Stimulating Hormone, SD: Standard Deviation & & \\
\hline
\end{tabular}

The ultrasonographic examination was done on the $21^{\text {st }}$ menstrual day by using GE logic P6 (GE Healthcare, Buckingomshare) ultrasound machine with a $6-10 \mathrm{MHz}$ endovaginal transducer. After placing the transducer in to the vagina, transverse and sagittal images at the uterus and ovaries were obtained. Color Doppler examination of the endometrium was performed with a $1.1 \mathrm{kHz}$ pulse repetition frequency (PRF) to evaluate a minimum flow velocity at $5 \mathrm{~cm} / \mathrm{sec}$. in the spiral arteries. Triplex mode examination included gray scale image combined with color frame and a flow spectrum on the spectral wave, resistance (RI) and pulsatility indexes (PI) were measured automatically by using the software program in the equipment. SPSS 16.0 for Windows was used for the statistical analysis 95\% confidence interval was considered. Continuous variables were analyzed with sample t-test and $\mathrm{p}<0.05$ was considered statistically significiant.

\section{Results}

No significant difference was reported in serum mid-luteal progesterone, basal FSH levels between two groups and similarly no significant difference was observed in terms of demographic characteristics like age and BMI $(p>0.05)$. Endometrial spiral arteries RI and PI values were found to be $0.48 \pm 0.08$ and $0.65 \pm 0.18$ in midluteal peri-implatation period of the fertile control group. This values in study group were detected as RI $0.54 \pm 0.07$, PI $0.80 \pm 0.16$. The difference in both indexes are statistically significant between two groups (RI $\mathrm{p}<0.009$, PI $\mathrm{p}<0.004$ ).

\section{Discussion}

It has been previously demonstrated that impedance of uterine and spiral arteries blood flow change periodically during the normal ovulatory menstrual cycle $(1,2,8)$. It is interesting that the lowest impedance at spiral artery blood flow has been detected just at the time at mid-luteal phase, during which endometrium has been transformed from proliferative phase to secretory phase $(2,8,9)$. At this specific time period blood supply of uterus is rich and implantation is most likely to ocur $(2,3,6,10)$. In addition to this it was reported that impedance of spiral artery blood flow in women with unexplained infertility was significantly higher than that of the fertile counterparts $(1,7)$. Similarly Steer et al. (7) suggested that decreased uterine perfusion might be a cause of unexplained infertility (7). 
We therefore hypothesized that impaired blood flow could be an important contributing factor to infertility in women with no other relevant cause was present.

There are various methods to assess the endometrial receptivity including endometiral biopsy and immunohistochemical analysis. The introduction of pulsed Doppler ultrasonography has provided a non-invasive mode of evaluation of uterine impedance and reveal physiological data, rather than anatomical information alone.

There was significant correlation of uterine PI and biochemical markers of endometrial receptivity including endometrial histological dating $(11,12)$. The measurement of impedance to uterine blood flow in IVF cycles has provided an indirect measure of endometrial receptivity $(9,11,13)$. In studies where endometrial and subendometrial blood flow were analysed by color or power Doppler ultrasonography absence of blood flow signal has been found to be associated with significantly low pregnancy rate or absence of pregnancy in IVF cycles $(13,14)$. Battaglia et al. (9) reported the highest pregnancy rate in the group with lower resistance to blood flow in the uterine spiral arteries. This finding revealing the decrease in peripheral impedance in the uterine vasculature reflected by a low uterine artery PI was considered to be a consequence of increased blood flow and a sign of high tissue perfusion, and this might be an important prerequisite for successful invitro fertilization and embryo transfer cycle. In this study the best uterine receptivity was a achieved in lower resistance group and no pregnancy were detected when PI>3.0. Similarly Steer et al. (11) reported that $35 \%$ of women who failed to conceive in on IVF programme had a mean uterine artery PI value $>3.0$. Therefore, they suggested that embryo cryopreservation in those patients with a uterine artery PI>2.99 for transfer in subsequent cycles should be considered.

In other studies it was also found that there was significantly lower impedance at uterine artery blood flow in the conception group than in non-conception group in IVF-ET program. When spiral artery $\mathrm{RI}>0.72, \mathrm{PI}>1.6$ were present or there was absence of vascular signal in spiral artery, endometrium was considered to be non receptive, endometrial condition was suboptimal and implantation was unlikely to occur, so the patient was at high risk of $\mathrm{ART}$ treatment failure $(11,15)$.

In our study we observed a significantly lower impedance in uterine vasculature infertile control group in comparison to unexplained infertility group. Despite the similar demographic parameters and luteal phase progesterone profile spiral artery PI and RI values in unexplained infertility group were significantly higher than fertile control group. These findings are in accordance with the ones in literature. Pulsed Doppler ultrasonography is technically difficult especially with tiny vessels like subendometrial signals and spiral arteries and operator dependant. This may be a limitation to the wide spread use of this technique. In our study all of the measurements have been performed by the same author and the operator was blinded to the groups an this may be considered as a positive effect on objective evaluation. In conclusion our results can be considered as a sign for a significant endometrial contribution as derivation of blood flow impedance to unexplained group. Mid-luteal or peri-implantation period Doppler measurements should be considered in infertility patients and if impedance to uterine vasculature is found to be high these patients may become candidates for therapies increasing the luteal blood low like aspirin and omega 3 in unexplained infertility and IVF patients $(16,17)$. Embryo freezing and subsequent hormonal preparation of endometrium can be considered.

\section{Conflict of interest}

No conflict of interest was declared by the authors.

\section{References}

1. The Practice Committee of the American Society for Reproductive Medicine, authors. Effectiveness and treatment for unexplained infertility. Fertil Steril 2006; 86: S111-4. [CrossRef]

2. Gong X, Li Q, Zhang Q, Zhu G. Predicting Endometrium Receptivity with parameters of spiral artery blood flow, Journal of Huazhong Universty of Science and Technology 2005; 25: 335-8. [CrossRef]

3. Isakson R, Tiitinen A, Reinikainen LM, Cacciatore B. Comparison of uterine and spiral artery blood flow in women with unexplained and tubal infertility. Ultrasound Obstet and Gynceol 2003; 21: 174-80. [CrossRef]

4. Abulafia O and Sherer DM. Angiogenesis of the ovary. Am J Obstet Gynecol 2000; 182: 240-6. [CrossRef]

5. Yllmaz N, Kılıç S, Madendağ Y, Madendağ İ, Özgün A, Özakşit G, et al. Endometrial parameters in IVF and IUI administration on elderly women. Turk J Med Sci 2010; 40: 343-8.

6. Battaglia C, Sgarbi L, Salvatori M, Maxia N, Gaillinelli A, Volpe A. Increased anticardiolipin antibodies are positively related to the uterine artery pulsatility index in unexplained infertility. Human reproduction 1998; 13: 3487-91. [CrossRef]

7. Steer CV, Tan SL, Mason BA, Campbell S. Mid-luteal-phase vaginal Doppler assessment of uterine artery impedance in a sub-fertile population. Fertil Steril 1994; 61: 53-8.

8. Goswamy RK, Williams G, Steptoe PC. Doppler ultrasound studies of the uterine artery in spontaneous ovarian cycles. Hum. Reprod 1988; 3: 955-9.

9. Battaglia C, Larocca E, Lanzani A, Valentini M, Genazzani AR. Doppler ultrasound studies of the uterine arteries in spontaneous and IVF stimulated ovarian cycles. Gynecol Endocrinol 1990; 4: 245-50. [CrossRef]

10. Raine-Fenning NJ, Campbell BK, Kendall NR, Clewes JS, Johnson IR. Endometrial and subendometrial perfusion are impaired in women with unexplained sub-fertility. Human Reproduction 2004; 19: 2605-14. [CrossRef]

11. Steer CV, Campbell S, Tan SL, Crayford T,Mills C, Mason BA, et al. The use of transvaginal color flow imaging after invitro fertilization to identify optimum uterine conditions before embryo transfer. Fertil Steril 1992; 57: 372-6.

12. Steer CV, Tan SL, Dillon D, Mason BA, Campbell S. Vaginal color Doppler assessment at uterine artery impedance correlates with immunohistochemical markers at endometrial respectively required fort he implantation at an embryo. Fertil and steril 1995; 63: 101-8.

13. Zaidi J, Campbell S, Pittrof R, Tan SL. Endometrial thickness, morphology, vascular penetration and velocimetry in predicting implantation in an in vitro fertilization program. Ultrasound Obstet Gynecol 1995; 6: 191-8. [CrossRef]

14. Chien LW, Au HK, Chen PL, Xiao J and Tseng CR. Assessment of uterine receptivity by the endometrial-subendometrial blood flow distribution pattern in women undergoing in vitro fertilization-embryo transfer. Fertil Steril 2002; 78: 245-51. [CrossRef]

15. Cacciatore B, Simberg N, Fusaro P, Tiitinen A. Transvaginal Doppler study of uterine artery blood flow in in vitro fertilization-embryo transfer cycles. Fertil Steril 1996; 66: 130-4.

16. Kuo HC, Hsu CC, Wang ST, Huang KE. Aspirin improves uterine blood flow in the peri-implantation period J Formos Med Assoc 1997; 96: 253-7.

17. Lazzarin N, Vaquero E, Exacoustos C, Bertonotti E, Romanini ME, Arduini D. Low-dose aspirin and omega-3 fatty acids improve uterine artery blood flow velocity in women with recurrent miscarriage due to impaired uterine perfusion. Fertil Steril 2009; 92: 296-300. [CrossRef] 